\title{
Typical case: herpes zoster
}

\section{Caso típico: herpes-zóster}

\author{
Guilherme Cristianini Baldivia ${ }^{1 *}$, Gustavo Silveira Graudenz ${ }^{2}$
}

${ }^{1}$ Medical Undergraduate Student at Nove de Julho University (Uninove), São Paulo, SP, Brazil

${ }^{2}$ Post-doctor in Allergy and Immunology, Faculty of Medicine, University of São Paulo (FMUSP). Professor at Uninove for the Medical Undergraduate Course and the Business Administration Masters and PhD Programs, São Paulo, SP, Brazil
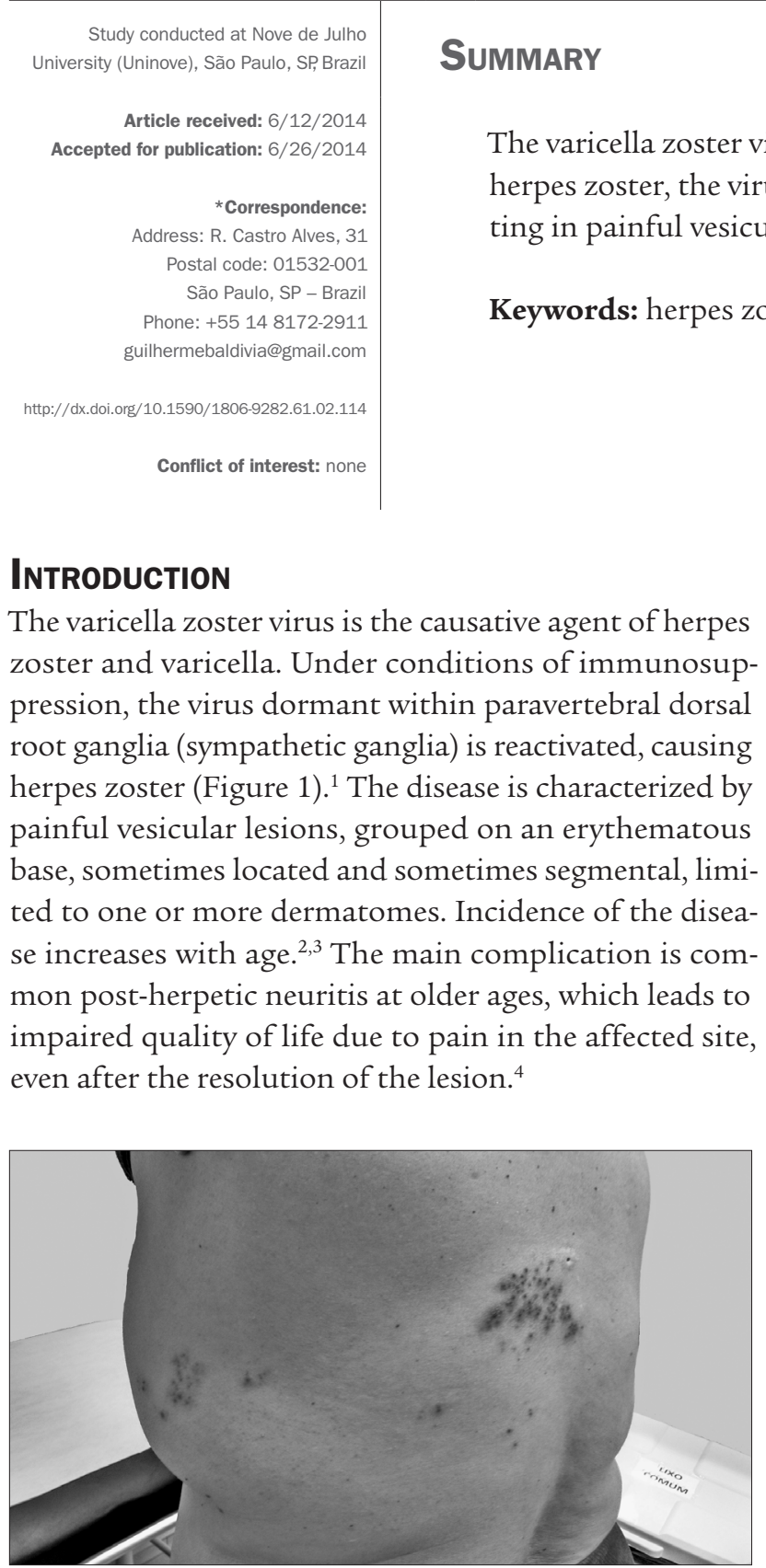

FIGURE 1 Paravertebral dorsal root ganglia (sympathetic ganglia) with serous crust.
Nonsteroidal anti-inflammatory agents, topical anesthetics or ice packs may be used in case of local pain. Keeping the sores clean prevents secondary infections. ${ }^{5}$ The recommended treatment with acyclovir significantly reduces viral replication, the formation of new lesions and the duration of symptoms in cases of recurrent herpes (81.5\% of cases). ${ }^{6}$

\section{Clinical case}

Woman aged 53 years, born and raised in the city of São Paulo, a retired teacher. The patient reported onset of itching in the left paravertebral region 1 week ago. The picture progressed after 3 days to the left submammary and left posterolateral regions, resulting in limited injury in the left $\mathrm{T} 5$ dermatome. The patient denies any habits or addictions.

The lesions were characterized initially by grouped vesicles forming clusters arranged on an erythematous base (Figure 2). As the lesions progressed, the vesicles erupted, forming a serous crust (Figure 1). Based on the predominant and characteristic lesion in the T5 dermatome, the diagnosis of herpes zoster was made and treatment with acyclovir $400 \mathrm{mg}$ for 5 days was requested.

\section{Resumo}

Caso típico: herpes-zóster. 


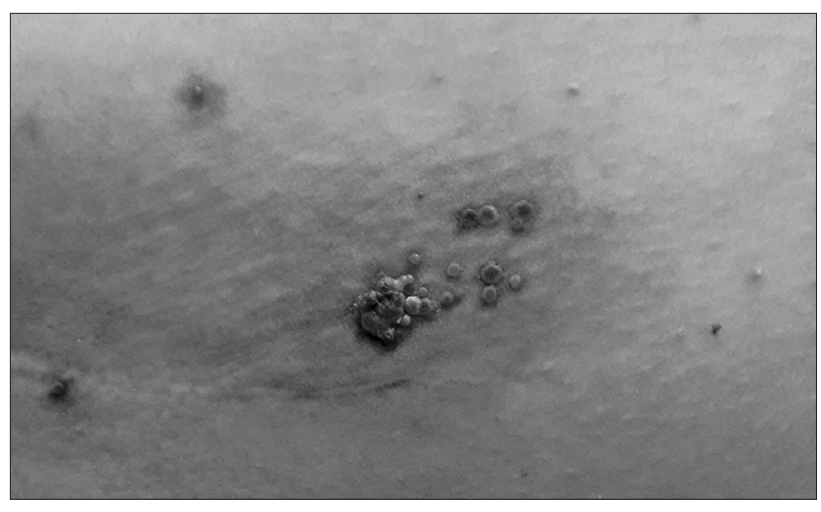

FIGURE 2 Grouped vesicles forming clusters arranged on an erythematous base.

O vírus varicela-zóster é o agente causador das doenças herpes-zóster e varicela. No caso do herpes-zóster, ocorre reativação do vírus que está alojado nos gânglios da raiz dorsal de gânglios simpáticos, resultando em lesões vesiculares dolorosas, agrupadas em uma base eritematosa.

Palavras-chave: herpes-zóster, gânglios simpáticos.

\section{REFEREnCES}

1. Pasternak J. Vacina contra herpes-zóster. Einstein (São Paulo). 2013 jan/ mar [acesso em 25 maio 2014];11(1):133-4. Available at: <http://www.scielo. br/scielo.php?script=sci_arttext\&pid=S1679-45082013000100026\&lng=e n\&nrm=iso>. http://dx.doi.org/10.1590/S1679-45082013000100026.

2. Bowsher D. The lifetime occurrence of Herpes zoster and prevalence of postherpetic neuralgia: A retrospective survey in an elderly population. Eur J Pain. 1999;3(4):335-42.

3. Schmader K. Herpes zoster in the elderly: issues related to geriatrics. Clin Infect Dis. 1999;28(4):736-9.

4. Johnson RW. Herpes zoster and postherpetic neuralgia: optimal treatment. Drugs Aging. 1997;10(2):80-94.

5. Sampaio SAP, Rivitti EA. Dermatologia. 3 ed. São Paulo: Artes Médicas, 2007. p.560-1.

6. Rompalo AM, Mertz GJ, Davis LG, Benedetti J, Critchlow C, Stamm WE et al. Oral acyclovir for treatment of first-episode herpes simplex virus proctitis. JAMA. 1988;259(19):2879-81. 